\title{
Immature granulocytes can help the diagnosis of pulmonary bacterial infections in patients with severe COVID-19 pneumonia
}

Thomas Daix ${ }^{1,2,3}$, Robin Jeannet ${ }^{1,4}$, Ana Catalina Hernandez Padilla ${ }^{1,2}$, Philippe Vignon 1,2,3, Jean Feuillard ${ }^{4,5}$ and Bruno François ${ }^{1,2,3^{*}}$ (e)

\begin{abstract}
During COVID-19, immature granulocyte (IG) concentration is heterogeneous with higher concentrations than those found in bacterial sepsis. We investigated the relationship between IG levels at ICU admission and on days $7( \pm 2)$ and $15( \pm 2)$ and associated pulmonary bacterial infections in intensive care unit (ICU) patients hospitalized for an acute respiratory distress syndrome (ARDS) related to SARS-CoV-2. Patients with associated pulmonary bacterial infection had a peak of IGs. IG thresholds of 18\% or $2 \mathrm{G} / \mathrm{L}$ allowed discriminating patients with ventilator associated pneumonia with $100 \%$ sensitivity and specificity. Our study supports that IGs could help identifying pulmonary bacterial infections in this population.
\end{abstract}

Keywords: Biomarker, COVID-19, Immature granulocytes, Secondary infections, Ventilator-associated pneumonia

\section{Introduction}

Patients hospitalized in the intensive care unit (ICU) with an acute respiratory distress syndrome (ARDS) related to SARS-CoV-2 frequently develop associated pulmonary bacterial infections, including ventilatorassociated pneumonia (VAP) which diagnosis is challenging in this clinical setting $[1,2]$. In bacterial sepsis and severe COVID-19, the myeloid cell compartment is dysregulated and circulating levels of immature granulocytes (IG) may increase [3, 4]. The range of IG increase appears highly variable in COVID-19 $[4,5]$. We previously showed that septic patients exhibit higher IG levels than patients with severe SARS-CoV-2 infection [3, 5]. We hypothesized that IG levels heterogeneity could be related to the development of pulmonary bacterial

*Correspondence: b.francois@unilim.fr

${ }^{3}$ Réanimation Polyvalente, CHU Dupuytren, 2 Avenue Martin-Luther King, 87042 Limoges, France

Full list of author information is available at the end of the article infections in patients mechanically ventilated for a SARSCoV2-induced ARDS.

\section{Methods}

Between December 2020 and March 2021, consecutive patients without known immunosuppression who required invasive mechanical ventilation for severe COVID-19 pneumonia were prospectively enrolled. The evolution of peripheral blood leukocyte populations were studied, from ICU admission to day $7( \pm 2)$ and day $15( \pm 2)$. Using flow cytometry, leukocyte populations were discriminated with CD3 for the T cells, CD19 for the B cells, CD14 for the monocytes, and CD16 for the granulocytes. CD45 was used to identify the hematopoietic cells and CD64 was used as a marker of neutrophils activation. Immature granulocytes or "band cells" were characterized as $\mathrm{CD} 45^{+} \mathrm{CD} 3^{-} \mathrm{CD} 19^{-} \mathrm{CD} 14^{-} \mathrm{CD} 16^{\mathrm{dim} /}$ neg (Fig. 1). Monocyte expression of HLA-DR, CD4 ${ }^{+}$and $\mathrm{CD}^{+} \mathrm{T}$ lymphocytes counts were also analyzed.

An independent committee blindly adjudicated the diagnosis of pulmonary bacterial infections during the original author(s) and the source, provide a link to the Creative Commons licence, and indicate if changes were made. The images or other third party material in this article are included in the article's Creative Commons licence, unless indicated otherwise in a credit line to the material. If material is not included in the article's Creative Commons licence and your intended use is not permitted by statutory regulation or exceeds the permitted use, you will need to obtain permission directly from the copyright holder. To view a copy of this licence, visit http://creativecommons.org/licenses/by/4.0/. The Creative Commons Public Domain Dedication waiver (http://creativeco mmons.org/publicdomain/zero/1.0/) applies to the data made available in this article, unless otherwise stated in a credit line to the data. 


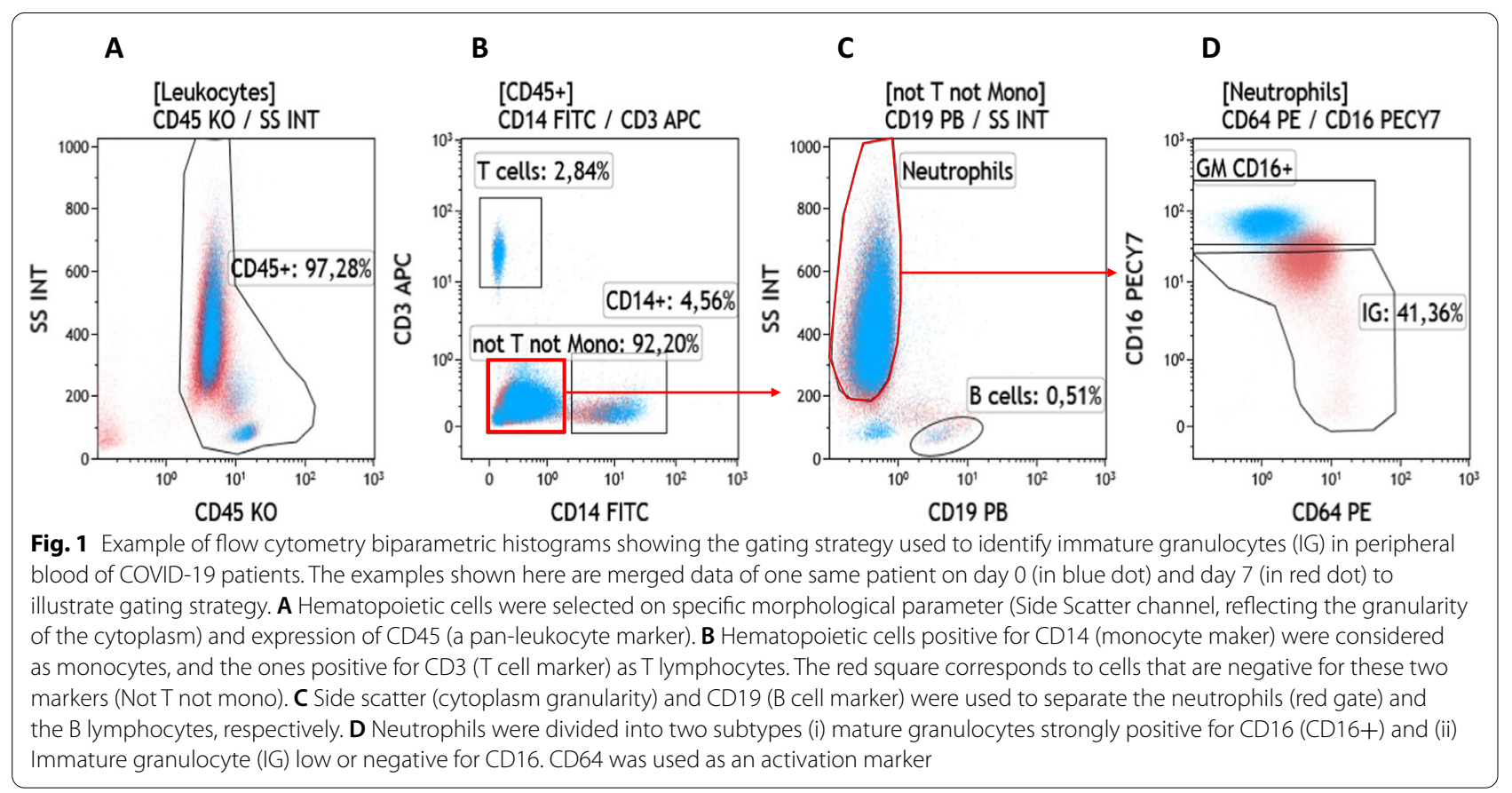

Table 1 Study population

\begin{tabular}{|c|c|c|c|}
\hline & Study population $(n=19)$ & $\begin{array}{l}\text { Bacterial pulmonary infection } \\
(n=12)\end{array}$ & $\begin{array}{l}\text { No bacteria } \\
\text { infection } \\
(n=7)\end{array}$ \\
\hline \multicolumn{4}{|l|}{ Demographics } \\
\hline Age & $72[63 ; 74.5]$ & $72.5[59.5 ; 73.8]$ & $70[65 ; 74.5]$ \\
\hline \multicolumn{4}{|l|}{ Gender } \\
\hline Male, $n(\%)$ & $13(68)$ & $10(83)$ & $3(43)$ \\
\hline $\mathrm{BMI}, \mathrm{kg} / \mathrm{m}^{2}$ & $26.8[24.5 ; 31.5]$ & $26.4[23.4 ; 31.2]$ & $27[26 ; 29.8]$ \\
\hline $\mathrm{BMI}>30, n(\%)$ & $6(32)$ & $4(33)$ & $2(29)$ \\
\hline \multicolumn{4}{|l|}{ Comorbidities, $n$ (\%) } \\
\hline Hypertension & $6(32)$ & $3(25)$ & $3(43)$ \\
\hline Diabetes & $6(32)$ & $4(33)$ & $2(29)$ \\
\hline COPD & $2(11)$ & $2(17)$ & 0 \\
\hline Chronic heart failure & $1(5)$ & $1(8)$ & 0 \\
\hline Chronic renal failure & $2(11)$ & $1(8)$ & $1(14)$ \\
\hline Immunosuppression & $1(5)$ & 0 & $1(14)$ \\
\hline \multicolumn{4}{|l|}{ ICU admission } \\
\hline SAPS $\|$ & $29[26 ; 35.5]$ & $29[26.5 ; 33.5]$ & $33[26 ; 39]$ \\
\hline SOFA score & $2[2 ; 4]$ & $2[2 ; 4]$ & $3[2 ; 3]$ \\
\hline Days from onset of disease to ICU admission & $8[6 ; 11]$ & $7.5[4.75 ; 9]$ & $10[9 ; 15.5]$ \\
\hline Steroids before ICU admission, $n(\%)$ & $3(16)$ & $2(17)$ & $1(14)$ \\
\hline Mechanical ventilation at ICU admission, $n(\%)$ & $5(26)$ & $4(22)$ & $1(14)$ \\
\hline Severe ARDS at ICU admission, $n(\%)$ & $7(37)$ & $3(25)$ & $4(57)$ \\
\hline Steroids, $n(\%)$ & $3(16)$ & $2(17)$ & $1(14)$ \\
\hline Dead at ICU discharge, $n(\%)$ & $6(32)$ & $6(50)$ & 0 \\
\hline
\end{tabular}




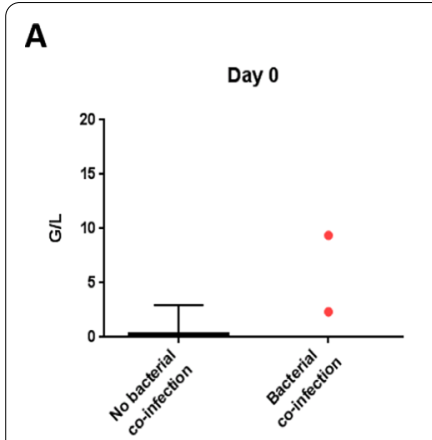

D

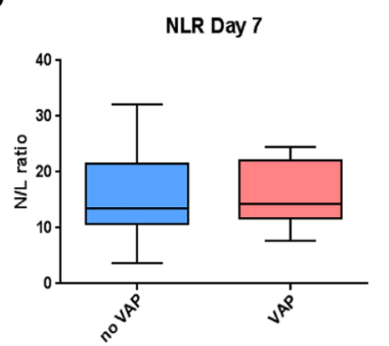

B

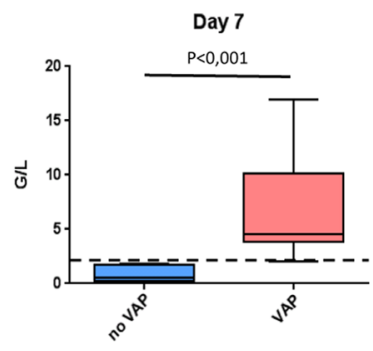

$\mathbf{E}$

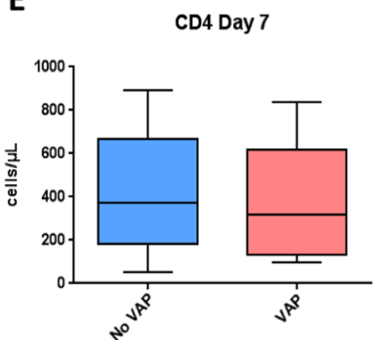

C

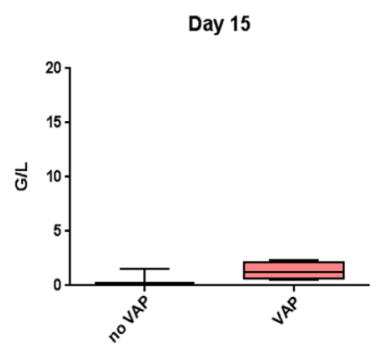

$\mathbf{F}$

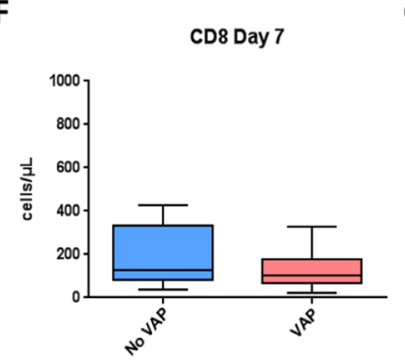

$\mathbf{G}$

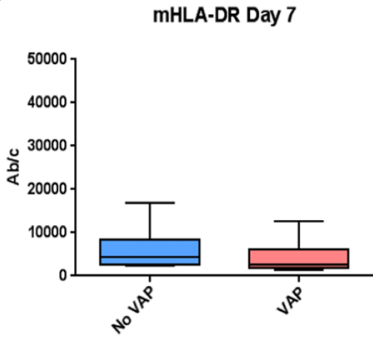

Fig. 2 A IG number in G/L in peripheral blood at Intensive care unit admission in COVID-19 patients without bacterial co-infection (blue, $N=17$ ) vs patients with bacterial co-infection (red, $N=2$ ). B IG number in $G / L$ in peripheral blood on day $7( \pm 2)$ in patients without VAP (blue, $N=7)$ vs patients with VAP (red, $N=10)$. The dot line represents the threshold separating patients with or without VAP. $C I G$ number in $G / L$ in peripheral blood on day $15( \pm 2)$ in patients without VAP (blue, $N=3$ ) vs patients that had VAP (red, $N=5)$. D Neutrophil to lymphocyte ratio (NLR) on day 7 $( \pm 2)$ in patients without VAP (blue, $N=7$ ) vs patients with VAP (red, $N=10)$. E CD4 lymphocyte absolute number in cell/ $\mu \mathrm{L}$ on day $7( \pm 2)$ in patients without VAP (blue, $N=7$ ) vs patients with VAP (red, $N=10)$. F CD8 lymphocyte absolute number in cell/ $\mu \mathrm{L}$ at day $7( \pm 2)$ in patients without VAP (blue, $N=7$ ) vs patients with VAP (red, $N=10)$. G HLA-DR expression on monocytes represented in antibodies bound per cell (Ab/c) on day 7 ( \pm 2 ) in patients without VAP (blue, $N=7$ ) vs patients with VAP (red, $N=10$ ). Results from $\mathbf{A}$ to $\mathbf{G}$ are represented in boxes (mean and interquartile range) and whiskers (min to max range); circles represent individual values. $p$ values were calculated using the Mann-Whitney test comparison

ICU stay based on clinical findings (fever, new onset of purulent endotracheal sputum or modification of sputum characteristics, auscultation abnormalities, increasing need of oxygen therapy), biological abnormalities (hyperleukocytosis, decreased $\mathrm{PaO}_{2} / \mathrm{FIO}_{2}$ ), radiological data (new onset or worsening of pulmonary infiltrate), and microbiological documentation. Pulmonary bacterial infections diagnosed within the first 2 days of ICU stay were considered as co-infections, while those diagnosed later were reported as VAP.

\section{Results}

Nineteen patients ventilated for severe COVID-19 were studied (72 [63.0-74.5] y.o; SAPS II: 29 [26.0-35.5]; mortality rate: $32 \%)$. Severity scores, comorbidities and steroids use were similar, irrespective of the presence of a pulmonary bacterial infection (Table 1). Two patients were admitted to ICU with a pulmonary bacterial co-infection, whereas 10 patients developed VAP (median diagnosis: 6.5 [4.3-7.8] days). On ICU admission, patients without pulmonary co-infection $(n=17)$ exhibited markedly lower circulating IG levels in absolute count $(0.40 \pm 0.75 \mathrm{G} / \mathrm{L})$ and in percentage $(3.22 \pm 3.78 \%)$ than those with bacterial co-infection
(2.30 G/L and $9.37 \mathrm{G} / \mathrm{L}$ in absolute count, or $75 \%$ and $84 \%$ in percentage) (Fig. 2A). In the two patients with bacterial co-infection at admission, IG absolute numbers and frequencies decreased with time (Additional file 1: Figure S1). On day 7, patients with confirmed VAP had a major peak of IG, both in percentage and absolute numbers, when compared to patients without VAP $(55.6 \pm 26.6 \%$ vs $9.0 \pm 5.9 \%, p=0.0001$ and $6.9 \pm 4.72 \mathrm{G} / \mathrm{L}$ vs $0.95 \pm 0.75 \mathrm{G} / \mathrm{L}, p=0.0002$; Fig. $2 \mathrm{~B})$. IG thresholds of either $18 \%$ or $2 \mathrm{G} / \mathrm{L}$ allowed discriminating patients with or without VAP with a $100 \%$ sensitivity and specificity (Fig. 2B). On day 15, IG levels decreased in patients who developed VAP on day 7 , and were close to those observed on ICU admission $(8.7 \pm 5.6 \%$ and $1.75 \pm 1.13 \mathrm{G} / \mathrm{L}$; Fig. $2 \mathrm{C}$ ). IG levels were moderately correlated to the SOFA score (Sequential Organ Failure Assessment) (Fig. 3; Spearman test $r=0.62$ ). Total neutrophil count tended to be increased in patients with VAP but without reaching statistical significance. No significant difference was noticed on day 7 in the neutrophil to lymphocyte ratio (NLR) (Fig. 2D). CD4 and CD8 T lymphocyte counts as well as HLA-DR monocyte expression were similar between patients (Fig. 2E, F). 


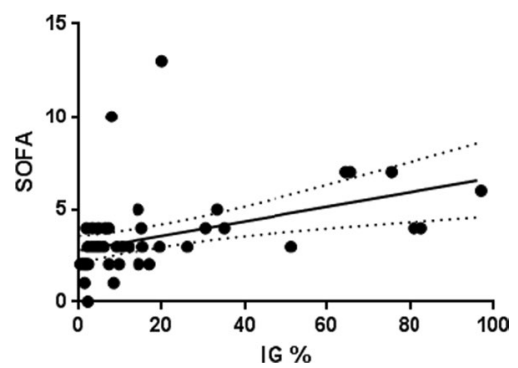

Fig. 3 Spearman correlation representation between sequential organ failure assessment (SOFA) score and immature granulocyte frequencies. The plain dark line corresponds to the linear regression and the dash lines correspond to the $95 \%$ confidence intervals

\section{Discussion}

Our results, even if obtained on a small cohort, suggest a strong association between level of IGs and pulmonary bacterial infection. Provided consolidation, they indicate that the peak of IG observed in case of bacterial associated infection could be a characteristic reaction of COVID-19.

In contrast to previous studies [4, 6, 7], IG levels were not associated with clinical severity in our patients as reflected by the absence of correlation between IG level and SOFA score. Nevertheless, the occurrence of secondary bacterial infection was not documented in these studies $[4,6,7]$. Associated pulmonary bacterial infections affect approximatively $50 \%$ of ventilated patients with severe COVID-19 [8]. This incidence appears superior to that observed in influenza or nonviral pneumonia [9]. In the clinical setting of acute viral ARDS, bacterial infection is associated with an increased risk of death [10]. In addition, radiological and clinical criteria are often inconclusive and, the diagnosis as well as the start of antibiotics mainly rely on microbiological documentation $[2,11]$. Due to the severity of SARS-CoV-2 pneumonia in ICU patients, the occurrence of an associated bacterial pulmonary infection requires early antibiotic therapy. Nevertheless, inappropriate antibiotic prescription could favor the emergence of multidrug resistant bacteria which could also jeopardize outcome. Therefore, a reliable biomarker would be highly beneficial in the context of the challenging diagnosis of associated bacterial infection in severe COVID-19.

Even if our results need to be validated by further larger scale studies, our proof of concept study supports that IGs could be an interesting biomarker of bacterial over-infections in ICU patients with severe COVID-19, especially since more and more hospitals have access to flow cytometry.

\section{Abbreviations}

ARDS: Acute respiratory distress syndrome; COVID-19: Coronavirus disease 2019; ICU: Intensive care unit; IG: Immature granulocyte; NLR: Neutrophil to lymphocyte ratio; SAPS: Simplified Acute Physiology Score; SOFA: Sequential Organ Failure Assessment; VAP: Ventilator-associated pneumonia.

\section{Supplementary Information}

The online version contains supplementary material available at https://doi. org/10.1186/s40560-021-00575-3.

Additional file 1. The figure shows the evolution of IG levels in the two COVID-19 patients with bacterial co-infection at admission on day $7( \pm 2)$ and day $15( \pm 2)$.

\section{Acknowledgements}

None.

\section{Authors' contributions \\ $T D, B F$, and PV included patients. RJ and JF performed the flow cytometry. RJ, $T D$, and $A H P$ analyzed the data. TD, RJ, and AHP drafted the manuscript. JF, $\mathrm{BF}$, and $\mathrm{PV}$ reviewed the manuscript. All authors read and approved the final manuscript.}

\section{Funding}

None.

\section{Availability of data and materials}

Not applicable.

\section{Declarations}

Ethics approval

Inserm CIC 1435 biobank: DC-2008-604.

\section{Consent to participate}

All patients agreed on the use of anonymized information as per the French law and the General Data Protection Regulation.

\section{Consent for publication}

Not applicable.

\section{Competing interests}

The authors declare that they have no competing interests.

\section{Author details}

${ }^{1}$ Inserm CIC 1435, Dupuytren Teaching Hospital, 87000 Limoges, France. ${ }^{2}$ UMR 1092, Faculty of Medicine, University of Limoges, 87000 Limoges, France.

${ }^{3}$ Réanimation Polyvalente, CHU Dupuytren, 2 Avenue Martin-Luther King, 87042 Limoges, France. ${ }^{4}$ UMR CNRS 7276, INSERM 1262, Faculty of Medicine, University of Limoges, 87000 Limoges, France. ${ }^{5}$ Hematology Laboratory, Dupuytren Teaching Hospital, 87000 Limoges, France.

Received: 6 July 2021 Accepted: 15 September 2021

Published online: 20 September 2021

References

1. Rouzé A, Martin-Loeches I, Povoa P, Makris D, Artigas A, Bouchereau M, et al. Relationship between SARS-CoV-2 infection and the incidence of ventilator-associated lower respiratory tract infections: a European multicenter cohort study. Intensive Care Med. 2021:47:188-98.

2. François $B$, Laterre P-F, Luyt C-E, Chastre J. The challenge of ventilatorassociated pneumonia diagnosis in COVID-19 patients. Crit Care. 2020;24(1):289. 
3. Daix T, Guerin E, Tavernier E, Mercier E, Gissot V, Hérault O, et al. Multicentric standardized flow cytometry routine assessment of patients with sepsis to predict clinical worsening. Chest. 2018;154(3):617-27.

4. Carissimo G, Xu W, Kwok I, Abdad MY, Chan YH, Fong SW, et al. Whole blood immunophenotyping uncovers immature neutrophil-to-VD2 T-cell ratio as an early marker for severe COVID-19. Nat Commun. 2020;11(1):5243

5. Jeannet R, Daix T, Formento R, Feuillard J, François B. Severe COVID-19 is associated with deep and sustained multifaceted cellular immunosuppression. Intensive Care Med. 2020;46(9):1769-71.

6. Kuri-Cervantes L, Pampena MB, Meng W, Rosenfeld AM, Ittner CAG, Weisman AR, et al. Comprehensive mapping of immune perturbations associated with severe COVID-19. Sci Immunol. 2020;5(49):eabd1 14.

7. Schulte-Schrepping J, Reusch N, Paclik D, Baßler K, Schlickeiser S, Zhang $B$, et al. Severe COVID-19 is marked by a dysregulated myeloid cell compartment. Cell. 2020;182(6):1419-1440.e23.

8. Blonz G, Kouatchet A, Chudeau N, Pontis E, Lorber J, Lemeur A, et al. Epidemiology and microbiology of ventilator-associated pneumonia in
COVID-19 patients: a multicenter retrospective study in 188 patients in an un-inundated French region. Crit Care. 2021;25(1):72.

9. Giacobbe DR, Battaglini D, Enrile EM, Dentone C, Vena A, Robba C, et al. Incidence and prognosis of ventilator-associated pneumonia in critically ill patients with COVID-19: a multicenter study. J Clin Med. 2021;10(4):555.

10. Chertow DS, Memoli MJ. Bacterial coinfection in influenza: a grand rounds review. JAMA. 2013;309(3):275-82.

11. Maes M, Higginson E, Pereira-Dias J, Curran MD, Parmar S, Khokhar F, et al. Ventilator-associated pneumonia in critically ill patients with COVID-19. Crit Care. 2021;25(1):1-11.

\section{Publisher's Note}

Springer Nature remains neutral with regard to jurisdictional claims in published maps and institutional affiliations.
Ready to submit your research? Choose BMC and benefit from:

- fast, convenient online submission

- thorough peer review by experienced researchers in your field

- rapid publication on acceptance

- support for research data, including large and complex data types

- gold Open Access which fosters wider collaboration and increased citations

- maximum visibility for your research: over $100 \mathrm{M}$ website views per year

At BMC, research is always in progress.

Learn more biomedcentral.com/submissions 